\title{
"Ye Are Many, They Are Few": Nonviolence as Response to Oppression and Repression in the Poetry of Percy Bysshe Shelley
}

\author{
George Ewane Ngide \\ Department of English, University of Yaoundé I, Yaoundé, Cameroon \\ Email: ngidengide@gmail.com
}

How to cite this paper: Ngide, G. E. (2020). "Ye Are Many, They Are Few": Nonviolence as Response to Oppression and Repression in the Poetry of Percy Bysshe Shelley. Open Journal of Social Sciences, 8, 530-554. https://doi.org/10.4236/jss.2020.86039

Received: April 27, 2020

Accepted: June 27, 2020

Published: June 30, 2020

Copyright ( 2020 by author(s) and Scientific Research Publishing Inc. This work is licensed under the Creative Commons Attribution International License (CC BY 4.0).

http://creativecommons.org/licenses/by/4.0/

\begin{abstract}
This article sets out to examine the relationship between the government and the governed in the works of Percy Bysshe Shelley. We posit that such a relationship is generally characterised by oppression and repression of the governed (the people, the many) by the government (the few, the ruling class). The ruling class inflicts pain of untold proportion on the masses that they subordinate and subjugate. As a result of the gruesome pain inflicted on them and the harrowing and excruciating experiences they go through, the masses are obliged to stand in defiance of the system and through nonviolence techniques they overthrow the governing class. This overthrow does not lead to a dictatorship of the proletariat rather it leads to a society of harmonious living. The Marxist theory of thesis, antithesis and synthesis is used to inform this argument.
\end{abstract}

\section{Keywords}

Oppression, Repression, Nonviolence, Government, Governed, Class

\section{Introduction}

"Ye are many, they are few" is a poetic statement made by Percy Bysshe Shelley in the poem "The Masque of Anarchy". It is a poem written in 1819 in the wake of what is now known as the "Peterloo Massacre". The poem calls for freedom and is considered the first modern statement of the principle of nonviolent resistance. Shelley considers "God, and King, and Law" as the unjust forms of authority. This "unholy trinity" is referred to as "they", the ruling class; and the "great assembly of ... the fearless, of the free", the People, the multitude is the "Ye" revered in the poem. Between the "they" and "Ye", Shelley seems to have 
taken sides with the "Ye", the masses, and prepares them for a peaceful resistance.

Studies in nonviolence as response to oppression and repression have constituted very interesting areas of academic investigations. Colaiaco (1986), Salla (2007a, 2007b), Chenoweth and Kathleen (2013), Mileski (2017) and others have studied the role of nonviolence in conflict situations between the government and the governed, basing on the principles as propounded by either Mahatma Gandhi or Martin Luther King. Chenoweth and Cunningham, for instance, opine that the events of the Arab Spring of 2011 have made clear the importance and potential efficacy of nonviolent resistance, as well as the field's inability to explain the onset and outcome of major nonviolent uprisings. Colaiaco (1986) examines the paradox of nonviolence as practised by Martin Luther king. He ascertains that as a student of Mahatma Gandhi's "soul force", King was very much aware that nonviolence in support of constitutional rights would lead to racist violence. Mileski on his part contextualises the nonviolent movements of King and Gandhi. Other scholars look at nonviolence as practised by Mandela (2013). It should be mentioned that Nelson Mandela himself in The Long Walk to Freedom records the nonviolent techniques used in the racist struggle in South Africa. Lal (2014) in "Mandela, Luthuli, and Nonviolence in the South African Freedom Struggle", on his part, discusses the trajectory of nonviolence from Gandhi to Mandela. He concludes that:

Experiments with nonviolence take place barely over a period of weeks, months, at best a few years, and are pronounced as failures, but such is the enchantment with violence that decades of violent struggle, leaving behind mounds of corpses and numerous trails of long-lasting bitterness, are still deemed by their architects and their supporters as insufficient time to assess their efficaciousness. The history of Mandela's relation to the question of violence and nonviolence, contrary to the impression sought to be conveyed by the ANC and Mandela himself, is thus far from settled at this juncture. (51)

What Lal insinuates above is that Nonviolence as a response to oppression and that repression is a technique whose efficiency still remains questionable.

However, in the brief discussion of nonviolence above, little or no mention is made of Percy Bysshe Shelley as the father of nonviolent techniques in combatting oppression and repression as a mover of socio-political change.

\subsection{Research Questions}

After this brief overview of nonviolence, a number of questions that need answers come to mind. What is the relationship between the government and the governed? Can nonviolence be an efficient tool in fighting oppression and repression? Can the governed overthrow the government through nonviolence? If they do overthrow the government, what kind of society upsurges? If Shelley is the father of nonviolence, why do the other nonviolent activists after him not acknowledge him? These and other questions inform our discussion of Shelley's 
vision of nonviolence as seen in his works, both poetic and dramatic.

Our intention here is principally to examine the relationship between the government and the governed and how the governed use nonviolence to combat oppression in order to create a harmonised society of equity and justice.

\subsection{Hypothesis}

In this study we opine that the relationship between the government and the governed is generally characterised by oppression and repression of the governed (the people, the many, the "Ye") by the government (the few, the ruling class, the "they"). The ruling class inflicts pain of untold proportion on the masses that they subordinate and subjugate. As a result of the gruesome pain inflicted on them and the harrowing and excruciating experiences they go through, the masses are obliged to stand in defiance of the system and through nonviolence techniques overthrow the governing class. This overthrow does not lead to a dictatorship of the proletariat rather it leads to a society of harmonious living and a society of fairness and justice.

\section{2. "They Are Few": Shelley's Indictment of the Ruling Class}

In this section, we intend to portray the hatred that Shelley has for the Ruling Class. The section also examines the plight of the governed through the oppressive treated meted out to them by the Ruling Class. Shelley considers the ruling class as the "They"; that set of "execrable" sons of nature who have dominion over fellow man. In this category, according to Shelley, are kings, the Clergy and other aristocratic political figures who govern the world by inflicting pain and misery on the many industrial workers. In his poetry, Shelley criticises and insults this class of people whose disappearance from the globe, he holds, will make the universe a paradise on earth because, like he says, the Clergy, "blast every human flower even in its tender bud". "Queen Mab", "Prometheus Unbound", "Hellas", "Oedipus Tyrannus", and a good number of his lyric poems and political pamphlets, six in number, do not only expose the pain inflicted on the governed and thus laying bare the wickedness of the government, but also propose ways by which the governed can fight back the government through nonviolence to establish a just society. Shelley's political vision and his personal involvement in the political fight are aimed at obtaining a just society, one where kings will be "sceptreless- just men".

\subsection{Oppression and Repression of the Working Class}

"Sonnet: England in 1819" and "Song to the Men of England" are two of such poems which address the plight of the working class and the oppressive ways of the ruling class. "Sonnet: England in 1819" for instance, describes the corrupt aristocracy as preying on the common people. The king is portrayed as "An old, mad, blind, despised, and dying king" (1). Shadrach Ambanasom (2001) states that: 
The despised king mentioned in the poem is King George III declared insane in 1811 and who died in 1820. The soldiers had massacred many people in a crowd that had assembled on St. Peter's Field in August 16, 1819, to carry out a peaceful rally in support of parliamentary reforms. The senate had imposed very hard and inhuman laws on dissenters and Roman Catholics. This explains the Christless and Godless religion practised by the official religion of England-Anglicanism. (115)

The king is despised because of his actions, and his ailing condition in 1819 produces no pity in the heart of the working class. King George III is lumped together with all other tyrants who serve him such as "princes" described as "mud from a muddy spring", and an army paid to kill. He has lost the senses of sight, feeling and knowledge and yet continues to rule his country (6). Shelley depicts the king as ignorant and blindly nationalistic. Furthermore, the aristocracy commits "liberticide" (9), meaning that they destroy freedom in all forms. Shelley presents the laws created by the ruling class as "Golden and sanguine" (11). This connotes laws that favour peace and promise hope, but Shelley adds that the laws only appear this way in order to "tempt and slay" (11). Laws, which are extensions of, and act as, reflections upon the aristocracy, are deceptive and detrimental to the people, according to Percy Bysshe Shelley. The furious and violent metaphors that Shelley employs throughout this list (nobles as "leeches in muddy water", the army as "a two-edged sword", religion as a "sealed book", Parliament as "an unjust law") leave no doubt about his feelings on the state of his nation. In the last part of "Sonnet: England in 1819", Shelley describes what he believes would be best for England. The Senate is ineffective and metaphorically dead. From this dead Senate, or outdated form of government, Shelley imagines "a glorious Phantom" (14) springing out. This phantom might be the collective revolutionaries and their philosophical ideals. Shelley does not tell precisely how this phantom will brighten the storminess of life in England, but it will clearly and permanently replace the much-hated Senate. The grave here has a dual significance. It is a symbol of destruction, of the end, and of annihilation, on the one hand, and a symbol of the fertile ground from which a revolution may spring on the other. It is equated to the dead leaves in "Ode to the West Wind" which are buried in winter to nurture young leaves in spring. The grave is also similar to the phantoms in their graves invoked by Shelley in "Hymn to Intellectual Beauty" to aid him in his night study so that he can eventually redeem "this world from its dark slavery". Desmond King-Hele (1960) traces the historical context of the poem. He posits that:

In the spring and early summer of 1819 Shelley had been occupied with high poetic themes, Acts II and III of Prometheus Unbound and The Cenci. On finishing the latter his mood changed, and during the autumn he cast a critical eye on the homeland he so often wanted to return to, her system of government, her people's wrongs, and the hardening of the arteries in her leading poet, Wordsworth. England in 1819, four years after the most exhausting war she had 
known, was still trying to jog along within the eighteenth-century pattern which events and inventions had rendered obsolete. The Prince Regent's nine years as head of the State had so signally failed to endear him to his people that he hardly ever dared show his face in public. His Prime Minister was the tactful and easy-going Lord Liverpool, who was halfway through his fifteen-year spell as Premier. The chief members of his Tory Cabinet were Castlereagh, Foreign Secretary and leader of the House of Commons, Eldon the Lord Chancellor, Lord Sidmouth the Home Secretary and Wellington, who was Master-General of the Ordnance. The government's home policy was one of studied inaction, punctuated by occasional repressive measures to scotch popular risings. (67)

As Yeşilyurt (2015) puts it in "Political Criticism in Percy Bysshe Shelley's England in 1819", the poet mostly "emphasises the wickedness of the ruling class against common people in England during the times of the French Revolution". In the poem, the writer expresses his hatred against the nobility of England. $\mathrm{He}$ creates metaphors which demonstrate how careless and ignorant the rulers are and how the public struggles with hunger, unemployment and even death. $\mathrm{He}$ makes references to several historical events such as Habeas Corpus Act, Peterloo Massacre and Napoleonic Wars. Shelley creates a totally unconventional sonnet form by using an upside down Petrarchan sonnet. Although "England in 1819 " is pessimistic in tone, Shelley proposes that there might be a radical change in the future which he states by creating the "Phantom" of revolution.

In "Song to the Men of England" Shelley addresses the impoverished working class who are exploited by the ruling class. Again, he criticises the system, but pays special attention to the mistreatment of those who work with the hand. The farmers are the ones who labour, yet they are not allowed to keep what they sow; they are asked why they "weave with toil and care/The rich robes your tyrants wear?" (3-4). Shelley sympathises with the working class, all the while demanding to know why they allow themselves to be exploited. He compares the masses to bees, insects that work their whole lives away so that the Queen (or King, in the case of England) does not have to perform any honest work herself. Shelley seems to both pity and scorn the working class for allowing themselves to be victimised by those in power. The pity and scorn are indirect ways of spurring them to stand against tyranny and encourage them to shake inertia.

Apart from downplaying the ruling class, Shelley looks at its power with cynicism. He abhors the ruling class, and seems to think that significant socio-political change is on the horizon. In "Ozymandias", Shelley explains his cynicism with the power of the ruling class and doubts its great impact on humanity as a whole. Shelley uses King Ozymandias of Egypt to illustrate how "mighty" rulers are worthless to humanity. Their power, like that of Ozymandias, will not withstand the test of time. Ironically, even though the king was very powerful, now, everything he stood for has been destroyed. He thought he was an important and mighty man, but his kingdom has decayed and is a "colossal Wreck, boundless and bare" (13). The mighty and dreadful nature of Ozymandias is re- 
vealed by the physical features of his statue. The words "frown", "sneer", "cold command" reveal the fact that he was stern, scornful, merciless and ruthless, and insensitive to the plight of his people. His boastful nature is translated by the expression "My name is Ozymandias, king of kings" (10). The expression "king of kings" connotes finality, the greatest among the great. But Shelley waters down and deflates the pride of Ozymandias in that, of all he thought he was and of all his works, "Nothing beside remains. Round the decay/Of that colossal wreck, boundless and bare/The lone and level sands stretch far away" (12-14). As if by divine intervention, nothing remains of the king. The final "lone and level sands" that "stretch far away" is not only an indication of the deflated pride and might of the king, but most especially signal the vanity of human political power as well as the equality of all human beings irrespective of their social or political status.

The same indictment of political power is expressed in "Similes for Two Political Characters of 1819". The two political characters are compared to "gibbering night-birds" (6), "shark and dog-fish.../Under an Atlantic isle/...Wrinkling their red gills...". (11-13) Similarly, they are compared to:

...two vultures sick for battle,

Two scorpions under one wet stone,

Two bloodless wolves whose drythroats rattle,

Two crows perched on the murrainedcattle,

Two vipers tangled into one (16-21).

In an acidly satirical tone, the two political characters are compared to dangerous, ferocious, and poisonous animals, reptiles and birds of prey. They are "vultures", "two scorpions", "bloodless wolves", "two crows" and "two vipers". They are ever ready to remorselessly devour their prey. The imagery used by Shelley to describe the two political characters of 1819 show his hatred for and scorn of the two characters who consider their subjects as "murrained cattle" (20). The word "murrained" is synonymous with red water fever or a similar infectious disease affecting cattle or other animals. It connotes a plaque, an epidemic and refers to beings subject to death like cattle. Put differently the "Men of England" are considered by political figures as worthless and prone to death. John Carter Wood (2004) says that the poem is one of the poems which Shelley wrote in 1819 in "a state of politicised indignation" after he had heard about the Peterloo massacre. He intimates that:

The poem is a grim satire aimed at Sidmouth and Castlereagh, two leading cabinet members in the hated Liverpool administration. Having compared the two politicians to ravens and "gibbering night-birds", in the third stanza Shelley brings in a reference to slave trade, turning the men into fish. (300)

Following in the same basic punchline are "A New National Anthem", "Lines Written during the Castlereagh Administration" and "Ode to Liberty". These poems also fall within the same Shelleyan thematic concern- that of a scathing criticism against the ruling class and a lampoon of political power wielders. "A 
New National Anthem" is a play on Royal and Revered words and is intensely seditious. It proposes a new queen of England to be praised instead of the "old mad blind despised and dying King", George the Third. The new queen is the symbol of Liberty who had been killed and buried and has to be raised "from England's grave". (2) The "God save the Queen!" is a way for Shelley to say that the Queen was better than George III and that:

Millions on millions, wait

Firm, rapid, and elate,

On her majestic state!

God save the Queen." (11-14).

Foot (1984) asserts that it was this poem which probably persuaded Shelley to include in his little political collection two more poems which later became famous. The first was the "Ode to Liberty", which is prefaced with Byron's assertion that the banner of Freedom is always flying against the wind. Byron admired Shelley above all else for his constant struggling against the political current. Shelley's enormous talents were used not to butter up the rulers of society (as Wordsworth, Southey and Coleridge did) but to attack those rulers from every vantage point; speaking truth to power.

"Lines Written during the Castlereagh Administration" is addressed not to the oppressed but to the oppressors. It was originally entitled "England" by Shelley. According to William Keach (1997), in "Rise like Lions?: Shelley and the Revolutionary Left" published by International Socialism, quarterly journal of the Socialist Workers Party (Britain) the change of title was justified. He explains that:

Thomas Medwin titled this poem "Lines Written during the Castlereagh Administration" when he first published it in the Athenaeum in December 1832, and editors have accepted the title ever since. But as Scrivener notes, by changing Shelley's own title as it appears in the Harvard Library transcription where it is simply headed "England"-Medwin "distances the political meaning of the poem for the 1832 audience". Shelley's "political meaning" in this case arises from an address not to the oppressed but to "thou Oppressor", although this rhetorical situation does not emerge clearly until the third stanza. (8)

The poem opens with a variation on the image of the grave that haunts all Shelley's political poems of 1819. The tone in the first two stanzas hovers between anger and despair:

Corpses are cold in the tomb;

Stones on the pavement are dumb;

Abortions are dead in the womb,

And their mothers look pale-like the death-white shore

Of Albion, free no more.

Her sons are as stones in the way,

They are masses of senseless clay,

They are trodden, and move not away,

The abortion with which she travaileth, 
Is Liberty, smitten to death. (1-10)

The word "masses" in line7 is interesting. The Oxford English Dictionary gives an example from 1837 as the earliest use of the phrase "the masses" to mean "the populace or "lower order", but Shelley's "masses of senseless clay" certainly anticipates this usage while preserving a figurative sense of aboriginal materiality. The question to be answered here is what is the attitude towards the capacity of the oppressed to resist and liberate themselves? Shelley, for all his liberating enthusiasm elsewhere, is here being either defeatist or condescending, or both. What is Shelley accomplishing, politically and poetically, by saying not only that Liberty is dead but that it or "she" has been, or is being, aborted?

In this poem and elsewhere in Shelley's works, abortions are images of horrible, deadly prematurely negations of all those images elsewhere in his writing of yet unborn potential and future rebirth. Anarchy itself, in "The Mask of Anarchy", becomes "the ghastly birth" that "Lay dead earth upon the earth", aborted by the emergent spirit of Liberty in an exact reversal of the image from the poem. The mock epithalamium which unfolds in the last three stanzas of the poem is a brilliant piece of Shelleyan grotesque. He taunts both the ruling class and the working classes:

Then trample and dance, thou Oppressor!

For thy victim is no redresser

And of the imagery of abortion from the first two stanzas:

Thou art sole lord and possessor

Of her corpses, and clods, and abortions they pave

The path to the grave. (11-16)

The "Oppressor" in this poem will abort himself in the very act of celebrating and consummating his marriage to "Ruin". A reader might be forgiven for thinking that this is not a revolution but an anarchist nightmare. She might ask, what is an "Epithalamium"? The word is right there at the end of the fourth stanza in what we can safely assume was one of the "popular songs" Shelley wanted to publish in 1819 , a vestige of the position of inescapable cultural superiority from which Shelley reached out to "the people".

Perhaps the most poignant of all of Shelley's revolutionary poems is "The Mask of Anarchy". Foot (1984) calls the poem "one of the great political protest poems of all time" (9). The poem describes the mass and rapid killing of the masses by a sanguinary government of 1819. It is a scathing revelation of what the government does to its people. It is also a call for resistance from oppression and murder. Written as a reaction to the "Peterloo" massacre, the poem was written, as Shelley says, "As I lay asleep in Italy/There came a voice from over the Sea/And with great power it forth led me/To walk in the visions of Poesy" (1-4). The main political figures in the poem are allegorical representations of the ruling class who claim that they are "... GOD, AND KING, AND LAW" (37). "Murder", "Fraud”, "Hypocrisy", "Anarchy" represent Castlereagh, Eldon, Sidmouth, and their followers who are described as "seven hounds", all "fat" and 
apparently very good-looking because Murder "tossed them human hearts to chew/Which from his wide cloak he drew" (12-13). In the company of Murder is Fraud who represents Eldon. He wears "an ermined gown" (15) and he shed "big tears" which "Turned to mill-stones as they fell./And the little children, who/Round his feet played to and fro,/Thinking every tear a gem,/Had their brains knocked out by them" (17-21). Sidmouth, represented here by Hypocrisy, rides on a crocodile and is "Clothed with the Bible" (22). Also with them are other "Destructions" "Like Bishops, lawyers, peers, or spies" (29). They are all disguised. In the parade of human destruction, maiming and killing, is Anarchy who rides "On a white horse splashed with blood; / He was pale even to the lips/Like Death in the Apocalypse/And he wore a kingly crown;/And in his grasp a sceptre shone;/On his brow this mark I saw — / I AM GOD, AND KING, AND LAW!" (31-37). They all move in "a pace stately and fast” (38) trampling to "a mire of blood/The adoring multitude" (40-41) as they passed "Over English land" (39). They are described as being "Drunk as with intoxication/Of the wine of desolation" and they pass through the fields and towns of England, "tearing up and trampling down" (52) everything along their path. As the deadly and dreadful convoy of Anarchy reaches London, every dweller is "panic-stricken" (54). He is on the contrary heartily welcome by lawyers, priests, the parliamentarians and all other companions of his, described by the speaker in the poem as "The hired murderers, who did sing, 'Thou art God, and law, and King/We have waited weak and lone/For thy coming, Mighty One!/Our purses are empty, our swords are cold,/Give us glory, and blood, and gold."” (339).

Anarchy is adored and revered by all those who wield a little parcel of his power. They join him in slaughtering and killing the people. Anarchy is described as a "Skeleton" (339) because he is devilish and inhuman. As in contemporary society, his supporters sing his praise. They torture and indulge in unmerited killing of the people. To anarchy they say, "Thou art King, and God, and Lord;/Anarchy, to thee we bow,/Be thy name made holy now!” (339). Like modern leaders in Africa and elsewhere, Anarchy "bowed and grinned to everyone" (339) in a show of self-pride and satisfaction, drunk with power.

"Queen Mab" also reveals the hypocrisy and tyranny of the ruling class as well as a critique against institutional morality. It was written by Shelley one year after "The Devil's Walk". The poem is written in the form of a fairy tale that presents a future vision of a utopia on earth, consisting of nine cantos and seventeen notes. Queen Mab, a fairy, descends in a chariot to a dwelling where Ianthe is sleeping on a couch. She detaches Ianthe's spirit or soul from her sleeping body and transports it on a celestial tour to her palace at the edge of the universe. She interprets, analyses, and explains Ianthe's dreams. She shows her visions of the past, present, and the future. The past and present are characterised by oppression, injustice, misery, and suffering caused by monarchies, commerce, and religion. The Fairy tells the spirit of Ianthe:

I am the Fairy $M A B$; to me' ts given 
The wonders of the human world to keep;

The secrets of the immeasurable past,

In the unfailing consciences of men,

Those stern, unflattering chroniclers, I find;

The future from the causes which arise

In each event, I gather, (765)

The past that is revealed to the spirit of Ianthe is one of injustice and the suffering of the people. The suffering is inflicted on them by the ruling class which comprises monarchs and religious personalities. In the past, "Monarchs and conquerors there/Proud o'er prostrate millions trod/The earthquakes of the human race;" (768). The people were killed in millions. "Trod" denotes the manner in which they were trampled upon while they lay "prostrate", that is, armless and harmless. The massive killing is compared to an earthquake which in turn informs the catastrophe caused by monarchs. The human race was "inhuman and uncultured", because, like the fairy puts it:

They rushed to war, tore from the mother's womb

The unborn child -old age and infancy

Promiscuous perished; their victorious arms

Left not a soul to breathe. Oh! they were fiends! (768)

"Rushed" in the excerpt above is telling of the rapidity with which the monarchs went to war. They did not take time to reflect on the consequences of their act of war. They were quick to kill and murder to the extent that even children in their mothers' wombs as well as the old were murdered. In other words, the monarchs and the conquerors exterminated an entire race. The past was also a bloody past where man drank "His enemy's blood, and, aping Europe's sons,/Wakes the unholy song of war," The King wears a gilded chain and he is called "Monarch". His heart is "bloodless" and even if "thousands groan", he remains indifferent. The monarch is here represented as a vampire that drinks human blood and as a sadist happy to see others groan. The fairy posits that:

His slumbers are but varied agonies,

They prey like scorpions on the springs of life.

There needeth not the hell that bigots frame

To punish those who err, earth in itself

Contains at once the evil and the cure, (771)

The monarchs are scorpions and the people are their prey. They have transformed the earth into a hell where the governed are in "varied agonies", under the pretext that they punish those who err. Kings and their "parasites" have a common origin and will have the same end:

From vice, black loathsome vice,

From rapine, madness, treachery, and wrong,

From all that genders misery, and makes

Of earth this thorny wilderness, from lust, 
Revenge, and murder. And when reason's voice,

Loud as the voice of Nature, shall have waked

The nations, and mankind perceive that vice

Is discord, war and misery, that virtue

Is peace and happiness and harmony,

When man's maturer nature shall disdain

The playthings of its childhood; -kingly glare

Will lose its power to dazzle, its authority

Will silently pass by, the gorgeous throne

Shall stand unnoticed in the regal hall,

Fast falling to decay, whilst falsehood's trade

Shall be as hateful and unprofitable

As that of truth is now. (772)

The earth has become "a thorny wilderness" where "revenge and murder", "misery" and "treachery" are rife and engendered by "the gorgeous throne", the monarch. "Wilderness" denotes the emptiness of the earth, made even more excruciating by the qualifying adjective "thorny". The wickedness of the monarch is likened to the colour "black" which insinuates devilish acts. Shelley, however, sounds a warning note, because the "black loathsome vice", the "madness" and "wrong" of the monarchs have an inevitable end. This will happen when man shall become mature and when "reason's voice,/Loud as the voice of Nature, shall have waked/The nations;" When man shall become reasonable and knowledgeable and begin to disdain the "playthings of its childhood", "kingly glare/Will lose its power to dazzle, its authority/Will silently pass by;" The past and present are painted in black where kings, priests and statesmen "blast the human flower/Even in its tender bud; their influence darts/Like subtle poison through the bloodless veins/Of desolate society." (776). This "unnatural line of drones", Shelley intimates, springs from "vice, black loathsome vice". History is a record of crimes and miseries. The example of Rome and Athens is edifying but a still greater darkness and misery succeeds both cities.

Where Athens, Rome, and Sparta stood,

There is a moral desert now.

The mean and miserable huts,

The yet more wretched palaces,

Contrasted with those ancient fanes

Now crumbling to oblivion,

The long and lonely colonnades

Through which the ghost of Freedom stalks,

Seem like a well-known tune,

Which in some dear scene we have loved to hear,

Remembered now in sadness.

But, oh! How much more changed,

How gloomier is the contrast 


\section{Of human nature there!}

Where Socrates expired, a tyrant's slave,

A coward and a fool, spreads death around

Then, shuddering, meets his own.

Where Cicero and Antoninus lived,

A cowled and hypocritical monk

Prays, curses and deceives. (165)

Evil is rooted in both the priest and king. The priest embodies superstition and the king embodies the exercise of power. The authority of the king is evil because he "spreads death around". He is considered "A coward and a fool" who has transformed Rome and Athens into "a moral desert now" replete with images of "mean and miserable huts" and "more wretched palaces". Graham Hough asserts that in "Queen Mab" Shelley is:

...too concerned with castigating and denouncing evil" to inquire into its metaphysical status, and the hall-mark of his poetry is the black-and-white opposition between the world of ideal beauty, freedom and virtue which is to come, and the almost unrelieved darkness of the past and present state of things. There is no bridge or explicable connexion between them; we pass in a sort of momentary trance from one world to the other... (126-127).

\subsection{The Poetic Dramas and Ruling Class Violence}

Shelley's lyric dramas like "Prometheus unbound" and "Hellas" carry the same message of the moral divide between the ruling class and the working class or the people both represented by the "They" and the "Ye" respectively. Although considered as dramatic works, Shelley's dramas carry the poetic imagination further and explain Shelley's vision even more clearly than the poems. This explains why we consider the dramas in this study. Another reason for this choice is that the dramas are wholly poetical in form and content.

The same moral divide of the representation of the good and the evil epitomised respectively in the masses or the people and the ruling class, is continued in "Prometheus Unbound". Prometheus is chained to a mountain in the Indian Caucasus, where his heart is daily devoured by Jupiter's eagle, while the two daughters of Ocean, Panthea and Ione sit silently at his feet. The pain is excruciating and the humiliation unbearable. Aided by his mother, the Earth, he starts to recall his curse of Jupiter. The Phantasm of Jupiter is called and repeats Prometheus's curse, and Prometheus's hatred for his adversary turns to pity. Mercury is sent by Jupiter with a vast chorus of Furies who tempt him to despair with visions of human inadequacy such as war, famine, industrial urbanisation, the failure of the French Revolution, and Christ's crucifixion. Panthea reminds Prometheus of his own eternal love, Asia, whom he has forgotten. Panthea also proclaims her own love for Asia and goes off to "the far Indian vale" to waken Asia. In Act II Prometheus does not appear. Panthea tells Asia of her dream of Prometheus rejuvenated by love, and together they follow the mysterious echo of 
a second dream to the dark underworld of Demogorgon, whom Asia, in scene IV, rouses into action with her passionate declaration of love for suffering humanity. A constant stream of chariots of the Hours pours up. One of these carries the grim fate of Jupiter, the other the happy reunion of Asia and Prometheus. In Act III Jupiter is overthrown by Demogorgon, and the unchained Prometheus is reunited with Asia in a forest cave. The Spirit of the Hour describes the universal liberation after the fall of kings and the end of social classes, nations and racial distinctions. In Act IV is a cosmic coda or epithalamium sung first by a chorus of Spirits of the Hour and another chorus of the Spirits of the Human Mind, then by the Spirit of the Earth and of the Moon.

Like "Prometheus Unbound", the subtitle of "Hellas" is "A Lyrical Drama". Like "Prometheus Unbound" and others of Shelley's Lyrical dramas, "Hellas" is motivated by a specific historical event and like all the other dramas, the divide between good and evil, the hypocrisy of the ruling class and the triumph of good and freedom are brought to sharp focus. Unlike other lyric dramas, however, critics seem to shy away from "Hellas". Very little has been written about the poem. Ralph Cohen (1984) uses the Reception Theory to explain the reason for the lack of critical interest in "Hellas". He states that:

...the first reception of a work by the reader includes a test of its aesthetic value in comparison with the works which he has already read. The obvious historical implication of this is that the appreciation of the first reader will be continued and enriched through further "Receptions" from generation to generation; in this way the historical significance of a work will be determined and its aesthetic value revealed. (12-13)

The low status of "Hellas" is thus dependent on the first critical reception. Because the first reaction to the poem was hostile, later critics continued to treat the poem that way, giving it a low reputation. In the evolution of literary history, then, "Hellas" was considered no match to other literary works. Mariann Cesilie Lokse (1994), in "In Defence of Hellas: An Analysis of Shelley's Hellas and its Reception," explores some reasons for the lack of interest in "Hellas". Among the reasons advanced are Shelley's early death, his Italian exile, the form of the poem, the subject matter with its exalted style and complex language as well as the "political content and difficult language employed" (17) plus Shelley's consideration of the poem in its preface as "a mere improvise" which indeed can be considered as a common topo of humility on his part. Lokse concludes that though "Hellas" is a "maze of inexplicable thought" the ideal of freedom and the indictment of the ruling class are ennobling visions that the poet upholds. Baker is right to consider the poem as a continuation of Shelley's other works on liberty. He argues that "it is part and parcel of his protracted effort to glorify the spread of liberty across the continent" (183). Young holds that the poem was written in the autumn of 1821 and was dedicated to Shelley's friend Prince Mavrocordato who was then fighting against the Turks for the cause of Greek independence. He adds that it was conceived on the model of Aeschylus's Persae and 
deals with Shelley's familiar themes such as:

Shelley's love of freedom and hatred of tyranny, his sympathy with the cause of the oppressed; and his cry that true freedom can only be achieved through a revolution of love. The poem is notable for Shelley's sympathetic study of the Turkish tyrant Mahmud, and for his refusal to propagandise an immediate victory through violence for his beloved Greece. (130).

Young thus disagrees with Carl Woodring (1970) who earlier thought that "Hellas" was "written by a would-be pacifist who has now chosen to praise wars and fightings" because "pacifism turns out to have been a limiting rule of reason" (316). According to Woodring, therefore, "Hellas" demonstrates that Shelley has accepted "violence as the means of securing independence" (317). This contradiction and difference of opinion are justified by the difficulty of the poem and thus confirms why many shy away from analysing "Hellas".

The story of the lyrical drama focuses on the Sultan, Mahmud, who controls the Turkish attacks on Greece. His sleep is restless and his mind worried by a recurring nightmare. He seeks help from the Wandering Jew, Ahasuerus, whom he believes has magic powers and can interpret his dream. During their conversation, Mahmud sinks more and more into despair as he, in spite of reports of Turkish victories, realises that he has lost the war. Alternating between the three dialogue parts, is a chorus of Greek, enslaved women who furnish the drama with hope and aspirations for freedom's victory. The chorus expresses a universalised view of the futility of war, their suffering and the tyranny of Mahmud. Mahmud is a tyrant. His dream and vision represent chaos and it is only after he understands his own dream that he recognises that his tyranny must fail. He is a slave master who lives in constant fear for both his life and his throne. The revolution of the Christian Greeks leads to his overthrow. His messengers tell him of the constant momentum and success of the revolutionaries. The second messenger tells him:

Nauplia, Tripolizza, Mothon, Athens,

Navarin, Artas, Monembasia,

Corinth and Thebes are carried by assault,

And every Islamite who made his dogs

Fat with the flesh of Galilean slaves

Passed an edge of the sword: the lust of blood

Which made our warriors drunk, is quenched in death;

But like a fiery plaque breaks out anew

In deeds which make the Christian cause look pale

In its own light. (465)

Like "Hellas", "Oedipus Tyrannus or Swellfoot the Tyrant" is another drama of Shelley which has remained seriously overlooked in scholarship. The play, however, stands as a key moment in the development of Shelley's thought and work. It demonstrates the poet's thoroughgoing understanding of political power. Significantly, it is a satire that arises out of a true historical moment in Eng- 
lish history. Upton Sinclair attests that the play is based on the history of George IV sued by his wife for divorce. As she puts it, "The odious fat lecher, King George IV, was sued for divorce by his wife, Queen Caroline, and it was a most horrible scandal, which Britain hardly dared to whisper" (2). Public opinion was in favour of the Queen but the King and the government devised a scheme to disgrace the Queen. The play thus describes the doomed scheme by which Swellfoot attempts to quell public support for the return of Queen Iona (Caroline) to her rightful seat of power. The play closely parallels George IV's desperate attempts to bar his wife, Caroline of Brunswick, from her spousal privilege incumbent upon his own accession to the throne. The deep connections between Shelley's satire and contemporary political events cannot be overlooked, for both Caroline of Brunswick and the play's heroine, Iona Taurina, function as highly visible emblems of the mother-whore, that revolutionary icon of the woman-in-public whose very presence threatens to feminise the public sphere and thus to hasten the collapse, the detumescence, to borrow an image central to Shelley's play, of masculine, patriarchal order. Young intimates that Shelley composed the play in August 1820 while reading poetry to a friend and that the local farmers of the surrounding area had brought their pigs to town for a fair. The clamorous noise that the pigs made "as they passed under the windows suggested to Shelley a frog's chorus in Aristophanes" (128). Young further states that at the same time all of England and Europe were watching with intense interest the divorce proceedings of Queen Caroline and the soon-to-be coronated George IV. The population took sides with the Queen and even if Shelley did not share in the public enthusiasm "he did seize the opportunity presented by pigs squealing in the street and people squawking in England to rapidly compose what one scholar has called "the only great Aristophanic lashing comedy, fantastic and grotesque, in our language" (128). The scholar Shelley is making allusion to is Seymour Reiter (1967) who, in A Study of Shelley's Poetry, has one of the most extensive and sympathetic analysis of the play. Swellfoot represents George IV and the pigs represent the suffering and oppressed masses. In Act I Swellfoot opulently boasts of his power and wealth. Together with his henchmen from the church and the state namely Mammon who represents Liverpool, and Purganax who represents Lord Castlereagh, tormenting and oppressing the swine of Thebes who represent the masses:
SWELLFOOT:
Thou supreme Goddess! By whose power divine
These graceful limbs are clothed in proud array
[HE CONTEMPLATES HIMSELF WITH SATISFACTION.]
Of gold and purple, and this kingly paunch
Swells like a sail before a favouring breeze,
And these most sacred nether promontories
Lie satisfied with layers of fat, and these
Boeotian cheeks, like Egypt's pyramid, 
(Nor with less toil were their foundations laid),

Sustain the cone of my untroubled brain,

That point, the emblem of a pointless nothing!

Thou to whom Kings and laurelled Emperors,

Radical-butchers, Paper-money-millers,

Bishops and Deacons, and the entire army

Of those fat martyrs to the persecution

Of stifling turtle-soup, and brandy-devils,

Offer their secret vows! Thou plenteous Ceres

Of their Eleusis, hai! (390)

It was Swellfoot's "kingly will/Us wretched swine to kill". The pigs and sows live a life of misery, poverty, hunger and even famine, while the king lives in affluence and pride.

FIRST SOW:

My Pigs, tis in vain to tug.

SECOND SOW:

I could almost eat my litter.

FIRST PIG:

I suck, but no milk will come from the dug.

SECOND PIG:

Our skin and our bones would be bitter.

THE BOARS:

We fight for this rag of greasy rug,

Though a trough of wash would be fitter. (392)

The pigs and sows represent the people or the suffering masses. Like pigs and sows, the suffering masses starve and as such they feed on their own "litter", they suck "but no milk will come from the dug" and all of them are skeletal and bony. The pigs, through the chorus, ask for better living conditions in a pleading and compassionate tone. They think that theirs is "an unhappy nation" and all they need is the barest minimum to sustain their existence:

To bind your mortar with, or fill our colons

With rich blood, or make brawn out of our gristles,

In policy-ask else your royal Solons

You ought to give us hog-wash and clean straw,

And sties well thatched; besides it is the law! (392)

The demand of the pigs and sows is considered "sedition and blasphemy" and Swellfoot instead summons his henchmen (Jews, Solomon the court porkman/Moses the sow-gelder, and Zephaniah/The hog-butcher) (69-71) to kill the pigs. His instructions are clear and limpid:

SWELLFOOT:

Out with your knife, old Moses, and spay those Sows

[THE PIGS RUN ABOUT IN CONSTERNATION.]

That load the earth with Pigs, cut close and deep. 
Moral restraint I see has no effect,

Nor prostitution, nor our own example,

Starvation, typhus-fever, war, nor prison

This was the art which the arch-priest of Famine

Hinted at in his charge to the Theban clergy

Cut close and deep, good Moses. (392)

Because of the suffering, hunger, humiliation and oppression incurred by the masses or the pigs, they are impatient to see the end of the brutal regime of King Swellfoot. This is why they rally behind Iona who represents Queen Caroline. They see in her a deliverer. There is general unrest around the kingdom and reports reaching the king are that his soldiers too are becoming treasonous by joining the masses against the king:

What is still worse, some Sows upon the ground

Have given the ape-guards apples, nuts, and gin,

And they all whisk their tails aloft, and cry,

Long live Iona! down with Swellfoot! (399)

This is a call for vengeance against the mistreatment of the Sows. Their "cry" while whisking "their tails aloft" is a strong sign of anger and a unquenchable desire to put an end to Swell-foot's reign of terror.

To these poems and the lyrical dramas treated above should be added Shelley's political pamphlets and major revolutionary poems. These also bear the mark of Shelley's political vision and his sympathies with the oppressed. The most prominent of these pamphlets were written while Shelley was living in Marlow. Because of their revolutionary ferment and indictment of political power, they were written under the pseudonym, "The Hermit of Marlow".

\section{3. "Ye Are Many": Nonviolence as Response to Oppression}

From a Marxist perspective, the tyranny and oppression of the government set the pace for a revolt of the masses, the people or the "Ye", either violent or nonviolent. The suffering masses have been prepared by the few despots to defend themselves in order to put an end to their hitherto plight of torture and come up with a more synthesising society where communal humanism is brought to the fore in the relations of governance. The triad, thesis, antithesis and synthesis are developed by Marx (1975) in his theory of Historical Materialism. In general terms a thesis is a starting point, an antithesis is a reaction to it and a synthesis is the outcome. Marx developed the concept of historical materialism whereby the history of man developed through several distinct stages, slavery, feudalism, capitalism and in the future communism. The movement from one stage to another could be explained by using thesis, antithesis and synthesis. Under capitalism the proletariat were exploited by the bourgeoisie who were the owners of the means of production. This was the thesis or starting point. The polarisation of the two classes would reach a stage where the proletariat would revolt against such exploitation. This was the antithesis. The outcome, in the long term would 
be a new form of relations within a classless society, namely communism. This would be the synthesis.

In" Sonnet: England in 1819" Shelley envisions a revolution that will be nonviolent. From this dead Senate, or outdated form of government, Shelley imagines "a glorious Phantom" (14) springing out. This Phantom might be the collective revolutionaries and their philosophical ideals. Shelley does not tell precisely how this phantom will brighten the storminess of life in England, but it will clearly and permanently replace the much-hated Senate. The grave here has a dual significance. It is a symbol of destruction, of the end, and of annihilation on the one hand, and a symbol of the fertile ground from which a revolution may spring on the other. It is equated to the dead leaves in "Ode to the West Wind" which are buried in winter to nurture young leaves in spring. The grave is also similar to the phantoms in their graves invoked by Shelley in "Hymn to Intellectual Beauty" to aid him in his night study so that he can eventually redeem "this world from its dark slavery". After twelve pessimistic lines, the poet finalises his work with these two optimistic lines: "Are graves from which a glorious Phantom may/Burst, to illuminate our tempestuous day." (13-14)

In these two lines, the reader encounters a new metaphor that the poet reflects one clear complete thought and hope about the state of England. He seems to propose a revolution or a big change that might occur in the future: The phantom of Revolution. With these two lines, he calls for a change, maybe even a revolution. He evokes the reader's feelings claiming that some change must happen so that England can get its "tempestuous day".

Although towards the end Shelley promises hope, his proposal is not free of negative connotations. This provides an ambiguous ending to the poem. One can interpret that the poet makes references to French Revolution since the poem was written right after the French Revolution. Having said that, it is obvious how Shelley knows about the fact that French Revolution was not glorious, for it resulted in terror and tyranny. Thus, he is unease about the idea of revolution. He knows that there must be some change and it will happen eventually, but he is not sure what is coming will bring salvation or not. Besides, the use of the word "Phantom" needs to be evaluated here. He does not use "ghost" or "spook". Phantom is a word that is less stable than the ghost. By using Phantom, he visualises and emphasises that what is coming may or may not be something that can save England from chaos, and make England stable again. The irregular metre used in the poem is a reflection of the chaos in England, for there is no proper metre in the poem.

"Song to the Men of England," aims to motivate the labourers to a revolution. Shelley recognises that they work only to have their products and profits seized by the ruling class. He urges that they take action rather than just complain about their problems. The course of action Shelley plans for the men is described in simple terms. What the farmers sow, they should not let tyrants reap. The robes they weave should not be worn by the lazy or leisure class. Perhaps most 
importantly, they should "Forge arms in your defence to bear." (24) The call to arms, although only in defence, encourages the lower classes to physically, even brutally defend their right to liberty. While he does not instruct the men of England to storm the Senate, he leaves them with the ambiguous suggestion of standing against the aristocracy, if necessary. This may be interpreted wrongly as a call for violence but on the contrary it is a tacit call for nonviolent resistance and non-cooperation as preached by Shelley.

Shelley supports his belief in working class empowerment by describing what their fate will be if they do not revolt against the oppressors. In a cynical and sarcastic tone, he suggests that the men who do not wish to "shake the chains ye wrought" (27) (or in modern terms, rock the boat) retreat to their "cellars, holes, and cells" (25). These are metaphors for the dark life and suffering of the working class. Living in holes suggests their homelessness. Their imprisonment and miserable life is also suggested by the image of cells and cellars. Shelley implies that they live not in homes, but in dark, dank, and lowly places whereas the elegant halls that they have decorated are being used by another, obviously the tyrant. Their dreary dwelling places then become mass graves that they dig for themselves. In other words, Shelley tells the men that if they continue to be sheepish, they should be prepared to "build" their "tomb" (30). If anything can stir up a revolutionary spirit in a person, it is the spectre of death. This is Shelley's prophetic message to the people, a call for a revolution that will change their status.

Percy Bysshe Shelley thus demonstrates his support of a revolution in these poems. He appears to be more of an activist in these works than he did in "A Defence of Poetry." Here, Shelley's ideas are practical, useful, and active. He does not only declare something to be innately wrong with the system, but also urges the English working class to take action so that the system can be changed.

In the "The Mask of Anarchy" Shelley's call for a revolution is clear. He calls on the masses not to relent in their fight for freedom. He indicts the masses because they do not know what freedom is. What they know is slavery because "its very name has grown/To an echo of your own". The masses work hard and get what "just keeps life from day to day". They "hunger for such diet/As the rich man in his riot/Casts to the fat dogs that lie/Surfeiting beneath his eye". The situation of the masses is so despicable that "at length when ye complain/With a murmur weak and vain/'Tis to see the Tyrant's crew/Ride over your wives and you - /Blood is on the grass like dew". Given the situation where the masses are considered as sub-humans, Shelley's calls on them to rise, use their numbers to effect the needed change. He incites them to;

"Rise like Lions after slumber

In unvanquishable number

Shake your chains to earth like dew

Which in sleep had fallen on you

Ye are many-they are few." (368-372) 
Shelley's rousing call to arms retains its power to excite and move. The largely monosyllabic final line, with its stresses on "ye," "man(y)," "they," and "few" not only creates a sense of authority but also subtly stresses Shelley's point of the necessity for the masses to shake-off inertia through nonviolence.

From stanza xxii the tone of the poem thus changes into an untold passive resistance masterminded by a "maniac maid" called "Hope" even if she "looked more like despair" (339) as a result of all the desperation and suffering inflicted on her and the population by the ruling class. The finality of the poem is a call for nonviolence and passive resistance against Anarchy and his company of "hounds". For Shelley, violence can only be combated with nonviolence and passive resistance.

In "Queen Mab" in spite of the misery, evil and torture of the past, the future is bright because every human heart contains the germ of perfection and all the institutions of evil, all the organs of authority, political and religious, shall wither. The link between the present miseries and the glorious future is the appearance of a saviour who "Shall bind the scorpion falsehood with a wreath/Of ever-living flame/Until the monster sting itself to death" (VI, 36-380). In the future, however, the condition of man will be improved and a utopia will emerge. The two key points emphasised are that death is not to be feared and that the future offers the possibility of perfectibility. Humanity and nature can be reconciled and work in unison and harmony, not against each other. While Ianthe is asleep on the couch, Henry waits to kiss her. He never does. Queen Mab returns Ianthe's spirit or soul to her body. Ianthe then awakens with a "gentle start".

Of the seventeen notes appended to the poem, six of them deal with the issues of atheism, vegetarianism, free love, the role of necessity in the physical and spiritual realm, and the relationship of Christ and the precepts of Christianity. The main thrust of the work is the perfectibility of man by moral means. Shelley's objective was to show that reform and improvement in the lot of mankind were possible. In her notes to the work, Mary Shelley explained the author's goals:

He was animated to greater zeal by compassion for his fellow creatures. His sympathy was excited by the misery with which the world is bursting. He witnessed the sufferings of the poor, and was aware of the evils of ignorance. He desired to induce every rich man to despoil himself of superfluity, and to create a brotherhood of property and service, and was ready to be the first to lay down the advantages of his birth. He was of too uncompromising a disposition to join any party. He did not in his youth look forward to gradual improvement. nay, in those days of intolerance, now almost forgotten, it seemed as easy to look forward to the sort of millennium of freedom and brotherhood, which he thought the proper state of mankind, as to the present reign of moderation and improvement. Ill health made him believe that his race would soon be run; that a year or two was all he had of life. He desired that these years should be useful and illustrious. He saw, in a fervent call on his fellow creatures to share alike the blessings of the creation, to love and serve each other, the noblest work that life and time permitted him. In this spirit he composed "Queen Mab" (Hutchinson, 
837).

Prometheus in "Prometheus Unbound" represents all that is good in suffering humanity. Jupiter represents the tyrannous and external evil by which humanity is oppressed. Jupiter is suddenly and mysteriously overthrown, and Prometheus is freed. At once the universe is cured of its disease, and all things rejoice in common. Shelley assumes the wickedness of Jupiter and the goodness of Prometheus. But Jupiter's wickedness has no motive, and his overthrow is causeless. Something happens in the middle of the play but Shelley cannot tell us what it is, perhaps because he does not know. Demogorgon appears and descends with Jupiter into the abyss but we do not learn why he appears or how he contrives the fall of Jupiter, or even who he is, except that he is Eternity and the child of Jupiter, as Jupiter of Saturn. Whatever the case, Jupiter who represents evil, tyranny and torture is defeated where Prometheus who represents goodness triumphs.

Young asserts that in "Hellas" although the Christian Greeks have victory over the pagan Turks represented by King Mahmud, their "cause look(s) pale" (554). This is because the Christians are as violent as the Turks. They do not hesitate to engage in the revenge ethic. Young continues by examining Shelley's dual position in the drama. He writes:

While Shelley admires the courage of the rebels (373-450), he condemns the violence with which men traditionally define their bravery. Shelley can be sympathetic to the Greeks and their cause, and yet recognise the pattern of the French Revolution in their actions. People enslaved for centuries under vicious tyrants at long last rebel, and the violence of rebellion rivals that of the despots and leads to the defeat of hopes for lasting peace and freedom. Because the Greeks have turned to violence, Shelley cannot foresee their immediate victory... (131-132).

The choruses in the play confirm the needless violence in the revolution because no matter who the victor is, the final outcome will be the death of mercy and brotherly love to the glory of man's inhumane revenge. For Shelley, violence is self-defeating because "Revenge and Wrong bring forth their kind,/The foul clubs like their parents are,/Their den is in the guilty mind,/And conscience feeds them with despair". (469) Emphasised in the drama is the cyclical view of history and prophesy that because Mahmud has submitted to history, history will destroy him. He is conquered as he conquered for the lesson of history works both ways, that is, men respond to violence with violence, and such violence brings reciprocal violence. There is no salvation for the violent and the tyrannical that have chosen to lock themselves in the cycles of history. Mahmud, like Ozymandias, has staked his immortality on his temporal glory and power, and time, he forgets, is a fickle guardian. The poem, however, ends with the return of "the world's great age", the "golden years". The new Greece and the new world can only establish its ideals of peace and brotherhood by escaping from the past through the "tears" of sympathy and the "flowers" of love. In other words, the future lies in the understanding of the trend of history and the absence of violence ushered in by "Reason" and "Imagination". The last chorus 
from the drama signals that utopia future:

The world's great age begins anew,

The golden years return,

The earth doth like a snake renew

Her winter weeds outworn:

Heaven smiles, and faiths and empires gleam,

Like wrecks of a dissolving dream...

Oh, cease! must hate and death return?

Cease! must men kill and die?

Cease! drain not to its dregs the urn

Of bitter prophecy.

The world is weary of the past,

Oh, might it die or rest at last! (477)

The government in "Swellfoot the Tyrant" designs the "Green Bag" scheme to hoodwink the swine into believing that Iona is guilty of sin and thus undesirably ugly. In Act II Purganax explains to the full assembly of Public Sty that the Green Bag holds a magic potion that when sprinkled over "A woman guilty ofwe all know what" (Act II, I, 83) will turn her into a hideous creature. If, however, she is innocent, the potion will turn her into an angel. This is to be the test of Iona.

John Pollard Guinn (1966) in Shelley's Political Thought argues that "the bag...is really filled with the concentrated poison of slander and sealed with the seal of fraud" (74). But before the despots execute their treachery, Iona empties the bag on them, thus trapping evil in its own villainy. She then mounts on the Minotaur, translated as John Bull, and leads the swine, transformed into bulls, in pursuit of violent revenge on Swellfoot and his acolytes. The Queen and the swine are thus victorious and they overthrow tyranny and villainy.

Samuel Gladden (2002) in Reading Shelley's Interventionist Poetry, 1819-1820 Shelley's Agenda Writ Large: Reconsidering Oedipus Tyrannus; or, Swellfoot the Tyrant holds that:

The swine's cries for victory over Swellfoot's tyrannical regime give voice to the political function they accord Iona's presence: "Hail! Iona the divine," they shout, "We will be no longer swine,/But bulls with horns and dewlaps" (1.1.277-279). Just as Iona's potential to disrupt Swellfoot's regime arms her with phallic power, so, too, do the swine anticipate the specifically gendered transformations their "divine" hero will bring them: freed from Swellfoot's tyranny by Iona, the swine will be transformed into bulls, their newly grown horns the outgrowth of the phallic transaction Iona has brokered. When Iona seizes Swellfoot's phallus to claim it as her own, she promises to distribute the power of that phallus equally among the commodities-among-themselves, the freed pigs-cum-bulls. (129)

Young agrees with Gladden that although Shelley imagines the Queen victorious over King George IV, he does not imagine a better society. This is because the Queen is equally committed to despotism and with "her vengeful and violent 
victory the oppressor and the oppressed have simply changed places and the circle begins again" (129). Shelley is, however, convinced that there is only one way to meaningful reform-the nonviolent way. This is why Shelley interrupts the play just before the Queen empties the Green Bag on her enemies, with a dramatic speech from the Spirit of Liberty to the Spirit of Famine:

O Famine!

I charge thee! When thou wake the multitude,

Thou lead them not upon the paths of blood.

The earth did never mean her foison

For those who crown life's cup with poison

Of fanatic rage and meaningless revenge

But for those radiant spirits, who are still

The standard-bearers in the van of Change. (408)

The speech of the Spirit of Liberty, doubtlessly, mars the sustained satire of the play but Shelley as a poet was always concerned more with meaning than with form. The interjection of the speech therefore serves to criticise the violence of Iona and the liberated swine. This alone establishes Shelley's commitment to nonviolence as a means of reform.

\section{Conclusion}

Shelley's poems and dramas treated above reveal the tyranny of rulers and those in power including men of God who, as he says in Charles the First "trod upon the heads of men:" (Act I, I, 60), "drunken with blood and gold", (61) are Machiavellian and "bolder than Judas" and thus crucify their God through their impious behaviour. Shelley, however, is convinced that these leaders who hang "leechlike to their fainting thrones" will one day "drop without a blow" and a new society of equity and justice created, naturally. But Shelley seems to warn that for such a society to exist, the governed, who eventually will overthrow the ruling class, must not return violence for violence. This is what he calls an "idealistic" revolution.

The oppressed in the dramas respond to the oppressor with violent vengeance even if at the end of each of the poems and plays there is no substantial change in the method of governance. What Shelley insinuates is that violence that begets violence makes the revolutionaries simply change roles and cloak themselves in the same violence that they combatted with vigour. By so doing, he imaginatively calls for nonviolent revolution. The imaginative call that runs across his dramas and poems is a demonstration of his maturity as an artist. It confirms his continuing commitment to nonviolence, the fallacy of revenge, as a logical, ethical, political and philosophical theory of life. In "Oedipus Tyrannus", the pretensions of the vengeful to build a better world through violence are satirically conveyed. Shelley's purpose, like Young successfully indicates, is to "attract people to nonviolence by imaginatively portraying its profundity, grandeur, beauty, and promise of utopia" (138) and this he achieves as pacesetter of nonviolent activism in the literature of all times. 


\section{Conflicts of Interest}

The author declares no conflicts of interest regarding the publication of this paper.

\section{References}

Ambanasom, S. (2001). The Radical Romantics: An Introduction. Yaoundé: Presses Universitaires de Yaoundé.

Chenoweth, E., \& Kathleen, G. C. (2013). Understanding Nonviolent Resistance: An Introduction. Sage Journals, 50, 271-276. https://doi.org/10.1177/0022343313480381

Cohen, R. (1984). The Cambridge Companion to Eighteenth Century Poetry. Cambridge: Cambridge University Press.

Colaiaco, J. A. (1986). Martin Luther King, Jr. and the Paradox of Nonviolent Direct Action. Phylon (1960-2002), 47, 16-28. https://doi.org/10.2307/274691

Foot, P. (1984). Red Shelley. London: Bookmarks.

Gladden, S. (2002). Shelley's Agenda Writ Large: Reconsidering Oedipus Tyrannus; or, Swellfoot the Tyrant. In: Reading Shelley's Interventionist Poetry from 1819-1820 (pp. 49-119). New York: Routledge.

Guinn, J. P (1966). Shelley's Political Thought. The Hague: Mouton.

Keach, W. (1997). Shelley's Style. New York: Metheun.

King-Hele, D. (1960). Shelley: His Thought and Work. London: Macmillan.

Lal, V. (2014). Mandela, Luthuli, and Nonviolence in the South African Freedom Struggle. Ufahamu: A Journal of African Studies, 38, 35-54.

Lokse, M. C. (1994). In Defence of Hellas: An Analysis of Shelley's Hellas and its Reception. Lrakse, Fag: Engelsk.

Mandela, N. (2013). Long Walk to Freedom: The Autobiography of Nelson Mandela. London: Little, Brown Book Group.

Marx, K., \& Engels, F. (1975). Collected Works. Introduction to Critique of the Hegelian Philosophy of Right (Vol. 3). London: Wishart.

Mileski, G. (2017). The Violence of Nonviolence: Contextualizing the Movements of King and Gandhi. Next, 5, Article 5. http://scholar.colorado.edu/next/vol5/iss1/5

Reiter, S. (1967). A Study of Shelley's Poetry. Albuquerque: University of New Mexico Press.

Salla, M. E. (2007a). Dedicated Minorities. Peace Review, 6, 241-248. https://doi.org/10.1080/10402659408425800

Salla, M. E. (2007b). The Efficacy of Nonviolence in International Relations: A Critique. Australian Journal of Political Science, 28, 458-480. https://doi.org/10.1080/00323269308402254

Shelley, M (1967). "Notes to Queen Mab” in Percy Bysshe Shelley: Complete Works (Ed. Thomas Hutchinson). London, Toronto: Oxford UP.

Shelley, P. B. (1887). The Hermit of Marlow: A Proposal for Putting Reform to the Vote throughout the Kingdom, Facsimile of the Holograph Manuscript. London: The Shelley Society.

Shelley, P. B. (1903). A Defence of Poetry (Albert Stanburrough Cook Ed.). London: Ginn.

Shelley, P. B. (1967). Shelley: Complete Works (Ed. Thomas Hutchinson). London, Toronto: Oxford UP. 
Wood, J. C. (2004). Violence and Crime in Nineteenth Century England: The Shadow of Our Refinement. London: Routledge. https://doi.org/10.4324/9780203391181

Woodring, C. (1970). Politics in English Romantic Poetry. Cambridge, MA: Harvard UP.

Yeşilyurt, S. D. (2015). Political Criticism in Percy Bysshe Shelley's "England in 1819". Trier: University of Trier.

Young, A. (1975). Shelley and Nonviolence. The Hague, Paris: Mouton. https://doi.org/10.1515/9783111709994 